IZA DP No. 4856

How Do Labor Markets Affect Crime?

New Evidence on an Old Puzzle

David B. Mustard

March 2010 


\title{
How Do Labor Markets Affect Crime? New Evidence on an Old Puzzle
}

\author{
David B. Mustard \\ University of Georgia \\ and IZA
}

\section{Discussion Paper No. 4856 \\ March 2010}

\author{
IZA \\ P.O. Box 7240 \\ 53072 Bonn \\ Germany \\ Phone: +49-228-3894-0 \\ Fax: +49-228-3894-180 \\ E-mail: iza@iza.org
}

Any opinions expressed here are those of the author(s) and not those of IZA. Research published in this series may include views on policy, but the institute itself takes no institutional policy positions.

The Institute for the Study of Labor (IZA) in Bonn is a local and virtual international research center and a place of communication between science, politics and business. IZA is an independent nonprofit organization supported by Deutsche Post Foundation. The center is associated with the University of Bonn and offers a stimulating research environment through its international network, workshops and conferences, data service, project support, research visits and doctoral program. IZA engages in (i) original and internationally competitive research in all fields of labor economics, (ii) development of policy concepts, and (iii) dissemination of research results and concepts to the interested public.

IZA Discussion Papers often represent preliminary work and are circulated to encourage discussion. Citation of such a paper should account for its provisional character. A revised version may be available directly from the author. 
IZA Discussion Paper No. 4856

March 2010

\section{ABSTRACT \\ How Do Labor Markets Affect Crime? New Evidence on an Old Puzzle ${ }^{*}$}

For nearly 50 years academics have been studying how labor markets affect crime. The initial interesting and important theoretical and empirical work generated substantial interest in studying crime among economists, in particular, and scholars in the social sciences more broadly. This literature, which is decades old and contains hundreds of papers, is characterized by an intriguing puzzle - the large gap between the theory and empirical work. While the hypothesis that growing labor markets reduce crime seems obvious and is widely accepted by many policy makers and academics, empirical results fail to show consistent evidence in support of this theory. The primary contribution of this chapter is to document how recent research - primarily since the late 1990s - makes substantial progress in resolving this disconnect between the theory and empirics. To accomplish this goal, I discuss a few very important empirical problems that until the last 10 years have not been systematically addressed. The central conclusion of this chapter is that recent research that addresses these important questions consistently provides evidence to buttress the contention that labor market opportunities have important effects on crime, especially property crime.

JEL Classification: $\quad$ J2, K14, K42

Keywords: crime, labor markets, unemployment, wages

Corresponding author:

David B. Mustard

Terry College of Business

University of Georgia

Athens, GA 30602

USA

E-mail: mustard@terry.uga.edu 


\section{Introduction}

For nearly 50 years academics have been studying the extent to which labor markets affect crime. Fleisher (1963) used data from the Uniform Crime Reports between 1932 and 1961 to examine how the unemployment rates of young males in Boston, Cincinnati, and Chicago affected juvenile delinquency. He estimated that elasticities of unemployment rates of males between ages 16 and 24 to crime were about .10 to .25. Fleisher (1966) explored census tract data from the Chicago area between 1958 and 1961 and data from 101 cities with population in excess of 25,000. He concluded that higher unemployment and lower median income of those in the poorest quartile both increased the arrests of young men.

Becker (1968) developed a formal theory of crime that modeled the social cost of crime, the cost of apprehension and conviction, the supply of offenses, and punishments. This approach links the number of offenses committed by an individual $\left(O_{j}\right)$ to his probability of conviction ( $\left.p_{j}\right)$, his punishment or fine if convicted $f_{j}$, and other variables $\left(u_{j}\right)$ as follows:

$$
O_{j}=O_{j}\left(p_{j}, f_{j}, u_{j}\right) \text {. }
$$

While this model provided the groundwork for further theoretical and empirical advances in the economics of crime, it primarily focused on how the supply of offenses is affected by changes in the probability of being caught and the fine incurred if caught, and said little directly about the link between legal labor market opportunities and crime, which occurs through $u_{j}$, the portmanteau variable.

Ehrlich (1973) developed a more complete theoretical treatment of crime and market opportunities. In his model, individuals allocate time to the legal and illegal sectors. Ehrlich argues that the average potential illegal payoff is proxied by the relative variation in the median value of transferrable goods and assets or family income and that the mean income level of those 
below the state's median proxies for the variation in the mean legal opportunities available to potential offenders. He uses a repeated cross-section of state-level data from the 1940, 1950, and 1960 Censuses, and employs two-stage least squares (2SLS) and seemingly unrelated regressions (SUR) to account for endogeneity.

Ehrlich finds that crime is positively related to both the median state income and the percentage of families that are below one-half of the median income. The elasticities are positive, statistically significant and greater than one. Variations in these variables explain more of the variation property than violent crime, especially murder. There is also a strong positive relationship between income inequality and property crime. However, he classifies the results of the effect of unemployment on crime as "generally disappointing". These estimated effects of unemployment on crime were "not stable across different regressions and do not appear significantly different from zero.” (p. 555).

This initial interesting and important theoretical and empirical work generated substantial interest in studying crime among economists, in particular, and scholars in the social sciences more broadly. Hundreds of papers analyze how labor markets affect crime, and many more discuss the relationship in some manner or control for labor market variables while exploring other questions related to crime. Many reviews have been published in this large and dynamic field. Some of the most prominent reviews include Long and Witte (1981), Freeman (1983), Chiricos (1987), Freeman (1995), Piehl (1998), Fagan and Freeman (1999), and Bushway and Reuter (2001). Levitt (2004) and Blumstein and Wallman (2006) are broader summaries that discuss the labor markets as a subset of many factors that affect crime.

The relationship between labor markets and crime is not the sole domain of academic researchers; policy makers also exhibit great interest in better understanding this relationship. 
Piehl (1998) describes how this topic has important implications for both macro-level policy and for micro-level interventions. To the extent that a vibrant economy and labor markets reduce crime, a stronger case can be made for pursuing pro-growth macro policies, such as tax reductions. If improved labor market opportunities help individuals devote more time and effort to the legal sector and less to illegal activity, there may be a greater justification for educational or job training programs.

An important and striking theme of the existing reviews is that the empirical work shows that labor markets have little consistent effect on crime, which is true for the estimated magnitude of the effects, the statistical significance, and even more surprisingly, for the sign of the effect. Early reviews, like Freeman (1983) and Chiricos (1987) generally find small, positive effects of unemployment on crime, but the results are inconsistent across studies and are certainly not major determinants of crime. Freeman (1983, p. 106) concludes that crime and unemployment “fail to show a well-defined, quantifiable linkage.” Chiricos (1987), who reviews sixty-three studies, describes the empirical evidence as "inconsistent, insignificant, and weak". Piehl (1998) asserts that there is surprisingly little evidence to support the proposition that economic conditions influence crime rates. She opens her chapter by stating, "While many citizens, policy makers, politicians, and academics assume that economic conditions drive crime rates, evidence of this relationship has proved elusive. As a result, there is a large disconnect between theory and empirical evidence on this point.” (p. 302)

This literature, which is decades old and contains hundreds of papers, is characterized by an intriguing puzzle-the large gap between the theory and empirical work. While the hypothesis that growing labor markets reduce crime seems obvious and is widely accepted by many policy makers and academics, empirical results fail to show consistent evidence in support of this 
theory. The primary contribution of this chapter is to document how recent research—primarily since the late 1990s—makes substantial progress in resolving this disconnect between the theory and empirics. To accomplish this goal, I discuss a few very important empirical problems that until the last 10 years have not been systematically addressed. The central conclusion of this chapter is that recent research that addresses these important questions consistently provides evidence to buttress the contention that labor market opportunities have important effects on crime, especially property crime.

Because the research on how labor markets affect crime is exhaustive, I do not attempt to document all the studies or topics pertaining to this relationship. Instead, where appropriate I cite the existing reviews that do an excellent job of summarizing the research at the time of their publication. This review is unique in that I structure it around important problems that researchers of this topic consistently face. These problems have historically jeopardized our ability to identify the model and establish causality, thus creating the gap between the theory and empirical work.

\section{Research Context}

Before examining the specific problems, it is helpful to provide some contextual background that includes the theory, data, and some important trends in the research. Because many reviewers carefully document the theoretical developments and variations, my remarks on this matter are brief. As discussed above, Ehrlich (1973) laid the theoretical underpinnings. Since then, criminologists, economists, and sociologists have further developed the theoretical details. Cantor and Land (1985), one of the seminal sociology papers in this field, articulates two hypotheses of how aggregate unemployment affects aggregate crime. The first is the criminal 
opportunity effect and the second is a criminal motivation effect. Reuter et al. (1990) and Freeman (1999) document how the majority of those who participate in the illegal sector simultaneously derive income from legitimate jobs. Supplying labor to both systems implies either that crime does not offer enough hours at a sufficiently high wage, and people supplement their income with other work, or crime and legal work are not substitutes. Piehl (1998) documents at least seven variations on the basic theory, some of which emphasize the behavior of individuals while others operate at the macro level.

There are also some more recent theoretical innovations. Burdett et al. (2003) use an equilibrium search model to allow crime, unemployment, and inequality to be endogenous. They document how the possibility of criminal activity can raise wage inequality among homogeneous workers and how the possibility of crime can naturally generate multiple equilibria. Consequently, two fundamentally identical neighborhoods may have different levels of unemployment, inequality, and crime. They also explore the general equilibrium effects of both anti-crime policies (like changes in the sentence length) and labor market policies, such as unemployment insurance. Huang et al. (2004) use a dynamic general equilibrium framework to study the relationship between unemployment and crime. In the context of this searchequilibrium model in which agents choose between legal employment and crime-related activities, crime acts like a tax on human capital by affecting the probability that a worker's earnings are subsequently appropriated. Like Burdett et al., Huang et al. (2004) find multiple steady-state equilibria with high crime, low education, long periods of unemployment, and poverty being correlated. Lochner (2004) develops a framework that examines how increases in human capital from education and training affect the opportunity cost of crime from foregone 
work and expected costs associated with incarceration. He studies the effects that education, training, wage subsidies, and enforcement policies have on criminal behavior.

Most of the research about labor markets and crime focuses on the United States, and the most commonly used source of aggregate data is the Federal Bureau of Investigation's Uniform Crime Reports (UCR). The UCR, which started in 1929 is a nationwide system whereby law enforcement officials compile reported offenses for seven felonies-murder, rape, robbery, aggravated assault, burglary, larceny, and auto theft. These seven offenses are referred to as Index I crimes and are classified into two groups. The first four are considered violent crimes or crimes against people, and the last three are considered property crimes. The FBI aggregates these reported offenses to the county, Metropolitan Area, state, and national levels. Because it does not systematically track other offenses like drug dealing, embezzlement, tax evasion, and money laundering by geographic area, the majority of research examines these seven offenses. Consequently, we know relatively little about how labor markets affect other crimes. The National Longitudinal Survey of Youth (NLSY) is frequently used for individual data. This longitudinal study started in 1979 as a nationally representative survey of 14 to 21-year-olds and oversamples minority and disadvantaged youth. Although it follows the respondents over time, its criminal participation questions were asked in only one year, thus precluding the opportunity to learn how individual propensities to engage in illegal activities change in different contexts. Other data sources include administrative records for specific police jurisdictions like Atlanta, Chicago, or New York.

The initial research was disproportionately at the national or state level, but over time research has increasingly used smaller areas of analysis—like counties, cities, neighborhoods, and individuals. Freeman (1995) and Levitt (2001) contend that the national level time series 
data yield little meaningful results. It is very important to examine smaller units of analysis because there is extensive variation in both local labor markets (Topel, 1994) and crime (Glaeser et al., 1996; Glaeser and Sacerdote, 1999). Frequently variation in crime and labor markets is greater within than across states. Consequently, research that utilizes smaller units of analysis generally shows a tighter nexus between labor markets and crime. Freeman (1995, p. 184) states, "The strongest evidence that economic incentives are important in determining the crime rate comes from studies of individuals.”

Until recently, nearly all of the empirical literature that examines the relationship between legal labor market opportunities and crime used data from the United States. Efforts to explore crime across nations show limited success. Cross-national data yield little persuasive evidence because of the difficulty in comparing data across nations and the many unobserved differences across nations in important factors that influence labor markets and crime. However, an interesting development has been the recent growth of high quality studies that examine the labor market-crime link within other nations. In the last few decades, the economic performance of the U.S. has far exceeded European economic growth. While labor market opportunities in the U.S. generally expanded between 1990 and 1997, Fougere et al. (2009) document how unemployment rates in France increased by about 50 percent during this same period. Also, property crime rates in Europe increased substantially relative to their American counterparts. Machin and Meghir (2004) document how property crime in the U.K. and Wales increased steadily since 1975. Property crimes and some violent crimes (although not murder) are now higher in many European nations than the U.S. While the rapid growth in studies from other countries is promising, the quality of these studies varies widely. From a methodological standpoint some international studies are similar to the methods used in the US 30 years ago- 
they suffer omitted variable bias, endogeneity, and measurement error, and do a poor job of truly identifying causal effects. At the same time, some studies with international data are technically sophisticated and use cutting edge empirical techniques. This chapter discusses many recent and quality studies from outside the United States. Because previous surveys are nearly silent on international research, this emphasis is another unique aspect of this review.

\section{Problems in Estimating the Effect of Labor Markets on Crime}

I now examine some important issues that those who study this problem need to address. I define each problem, examine the progress that has been made in solving the problem, cite papers that address the concern, and outline areas for future research.

\section{A. Omitted variable bias}

To the extent that variables omitted from the regression are correlated with our measures of labor market success, there is scope for omitted variable bias. Early studies, like Fleischer (1963, 1966) and Ehrlich (1973), include only a few control variables, which make it difficult to control for unobserved differences across areas that may affect crime. Unfortunately, this problem persisted, as all but a few studies written through the early 1990s control for more than a half-dozen variables. Fortunately, as data collection and computing capacity increased substantially over time, there has been marked progress in the ability to reduce the scope of omitted variables by controlling for an extensive array of economic, social, demographic, and criminological factors.

However, even after including a host of control variables, there may still be omitted variable bias because there are unobserved differences across regions that are correlated with 
labor markets or criminal activity. An important development in mitigating omitted variable bias from unobserved variables is the increased use of panel data estimation techniques that allow researchers to control for time and area fixed effects and area-specific time trends. In the last ten years many studies have used such techniques, and these studies consistently document a relationship between some labor market measure and crime.

Doyle et al. (1999) use U.S. state-level panel data from 1984 to 1993 to estimate how wages influence crime. They use fixed effects to control for unobserved heterogeneity across states, and measure labor market opportunities with an expected wage that considers wages, unemployment compensation, and the unemployment rate. They find strong evidence that wages, especially those in low-skilled sectors, decrease both property and violent crime, and that wages explain a greater amount of variation in crime than do unemployment rates.

Raphael and Winter-Ebmer (2001), who use state-level panel data from 1970 to 1993, include state-specific time trends, state effects, and year effects. Their results indicate that a substantial portion of the decline in property crime rates during the 1990s is attributable to the decline in the unemployment rate, with much weaker effects on violent crime.

Gould et al. (2002) run panel regressions using county, metropolitan area (MA), and state-level data from 1979-1997 with time and area fixed-effects. They conclude that both wages and unemployment of low-skilled males affects crime, and that the effect of wages on crime is greater than the effect of unemployment.

Papps and Winkelman (2002) study panel data for sixteen New Zealand regions between 1984 and 1996. The authors use both random and fixed effects models to establish causality between unemployment and crime, and conclude that unemployment raises both crime totals and some subcategories of crime. 
The New Earnings Survey (NES) provides Machin and Meghir (2004) with panel data on the police force areas of England and Wales between 1975 and 1996. While they conclude that the unemployment rate is not statistically significant, they assert that many wage measures consistently reduce property crime.

A panel of Swedish counties between 1988 and 1999 laid the foundation for Edmark (2005). Because this period in Sweden is characterized by turbulence in the labor market and great variation in unemployment rates, it provides a unique opportunity to examine unemployment effects. Her results show that unemployment has a positive and statistically significant effect on the property crimes of burglary, car theft and bike theft.

Arvanites and Defina (2006) use state-level panel data from 1986 to 2000 to study the conceptual framework of Cantor and Land (1985) that distinguishes between opportunity and motivation effects. Instead of using the unemployment rate, which is the most commonly used variable, they develop alternative measures that more faithfully capture the logic of the argument. They conclude that the strong economy of the 1990s reduced all index property crimes and robbery.

Using unique district-level panel data from Bavaria between 1835 and 1861, Mehlum et al. (2006) estimate the effect of poverty on crime. They use rainfall to instrument the price of rye, which was the primary determinant of living standards at that time, and conclude that a onestandard deviation increase in the price of rye raised property crime by 8 percent.

Ihlanfeldt (2007) investigates panel data of census tracts to explore the relationship between drug crime and young males' intra-urban job accessibility. Controlling for time and fixed effects along with many other potential sources of bias, he documents how modest 
improvements in job access can substantially reduce the amount of drug crime within poor innercity neighborhoods.

By including many control variables and using panel data strategies, these studies net out both observed and unobserved differences across regions. This research identifies the relationship between labor markets and crime from variations over time within areas rather than across areas. In doing so, this research reduces the scope of omitted variable bias and consistently concludes that labor markets (especially wages) have important roles in reducing crime. These results are encouraging in that they are being documented not only in the United States, but also in nations throughout the world.

\section{B. Reverse Causality}

Reverse causality, discussed by Ehrlich (1973) is a very important, but rarely analyzed identification problem in this literature. To the extent that crime affects labor markets, the OLS estimates of crime on labor market measures will be biased. Freeman (1995) and Piehl (1998) survey a few papers that examine this endogenous effect. Some research, primarily which focuses on those who have been convicted of crime or who have spent time in prison finds no effect or only a moderate effect of criminal participation on earning capacity. Using a sample of male arrestees from California, Grogger (1995) concluded that the earnings and employment effects are relatively short-lived, that convictions have little effect on future earnings, and that probation has no effect on arrestees' subsequent earnings. In a sample of prison releases, Needles (1996) concludes that the length of time in prison did not affect the earnings of those who participated in the legal labor market. 
In contrast, most studies conclude that criminal participation has a significant impact on both subsequent legal employment and earnings. Those who have been convicted of a crime or who have been incarcerated could experience reduced earnings through a variety of mechanisms, such as the loss of personal professional licenses, increased difficulty in obtaining employment, exclusion from some unions, harmful reputational effects, and the delay or denial in obtaining a business licenses. In addition, their future earnings may be reduced by recidivism, because those who are incarcerated have an increased risk of recidivism. Using the NLSY, Freeman (1992) estimates that a young male who was in prison in 1979 worked about 25 percent less during the subsequent eight years than a similar young man who had no prison record. Lott (1992) estimates the monetary penalty borne by those convicted of drug offenses and contends that those who return to the labor force suffer large penalties in the form of reduced legitimate earnings, and that the overall penalty increases dramatically with the level of pre-conviction income. He concludes that on average, lost post-conviction income accounts for between 35 and 96 percent of the total pecuniary penalty.

Sampson and Laub (1990) analyze the data from the Glueck and Glueck (1950) study of delinquent and non-delinquent boys born between 1924 and 1935. They conclude that seven indicators of adult crime and deviance are much more prevalent among men who were childhood delinquents. Sampson and Laub (1997) estimate that time in jail reduces job stability and elevates the risk of recidivism. Allgood et al. (2006), who examine a broadly representative sample of young males rather than studying only ex-offenders, find that although having been charged with a crime has little impact on future wages but being convicted lowers future earnings by about 10 to 12 percent. 
Crime may also influence the decision of firms to relocate or expand, thus affecting overall employment opportunities. Greenbaum and Tita (2004) use panel data at the ZIP code level to examine the effect of violence surges on the creation, destruction, and growth of business establishments in five large US cities between 1987 and 1994. After controlling for pre-existing levels of violence, they find that increases in the homicide rate reduce the number of new businesses and the growth of employment in existing firms; an effect that is greatest for servicerelated establishments.

The direction of the potential endogeneity bias is not entirely clear a priori. Cullen and Levitt (1999) contend that high-income individuals and employers leave areas with high or increasing crime rates. Conversely, Willis (1997) concludes that low-wage employers in the service sector are more likely to relocate due to increasing crime rates. Also, higher crime rates may force employers to pay higher wages as a compensating differential to workers (Roback 1982).

Previous reviewers urged researchers to address endogeneity more seriously. Levitt (2001) and Bushway and Reuter (2001) both highlight the importance of dealing with endogeneity as a condition for making future strides in this area. Piehl (1998) clearly and succinctly states, "The literature on economic conditions and crime needs empirical studies that use simultaneous models, so that the causality of crime on economics and that of economics on crime are both incorporated." In spite of these encouragements to address endogeneity, only a few papers that evaluate labor markets and crime try to address this concern.

In their state-level panel data set, Doyle et al. (1999) apply a GMM estimator to control for simultaneity bias and find strong evidence that wages decrease both property and violent crime and that income inequality has no effect on crime. Raphael and Winter-Ember (2001), who 
study state-level panel data from 1970 to 1993, use defense contracts and a state-specific measure of exposure to oil shocks as instruments for unemployment rates. Using 2SLS they estimate that the elasticity of unemployment on property crime was about 2.8 to 5.0 percent, about twice as large as their OLS estimates. These results of unemployment on property crime rates are stable across model specifications and imply that a substantial portion of the decline in property crime rates during the 1990s is attributable to the decline in the unemployment rate. Their evidence for violent crime is considerably weaker.

To develop instruments Gould et al. (2002) interact three sources of variation that are exogenous to the change in crime within each state: (1) the initial industrial composition in the state, (2) the national industrial composition trends in employment in each industry, and (3) biased technological change within each industry, as measured by the changes in the demographic composition within each industry at the national level. They also exploit crossindustry variations in the changes in industrial shares of four demographic groups (gender interacted with educational attainment). For example, the trends in the Michigan automobile industry and the Bay Area computing technology sector are extremely different. The decline in the auto industry's share of national employment will adversely affect Michigan's demand for labor more than California's. If biased technological change causes the auto industry to reduce its employment of unskilled men, this affects the demand for unskilled labor in Michigan more than in California. They conclude that endogeneity is not responsible for the significant relationship between the labor market conditions of unskilled workers and the various crime rates.

Lochner and Moretti (2004) contend that the underlying education and human capital affects individuals' labor market prospects. Using data from the NLSY, Census, and UCR, they 
estimate the effect of education on participation in criminal activity using changes in state compulsory schooling laws over time to account for the endogeneity of schooling decisions. They assert that schooling significantly reduces the probability of incarceration and arrest, and estimate that the social savings from crime reduction associated with high school graduation for men is about 14 to 26 percent of the private return.

Lin (2008) analyzes a panel of states from 1974 to 2000. Using OLS, Lin finds that a one-percentage-point increase in the average unemployment rate raises property crime by 1.8 percent. To instrument unemployment, Lin uses the changes in the real annual exchange rates multiplied by the percentage of state manufacturing sector employees of GDP value. The real exchange rate is calculated by the average foreign exchange rates of all trade partners weighted by trade volume. By weighting the manufacturing employee percentage, Lin measures the specific changes in the real exchange rate dollar appreciation to which each state is exposed in a given year. These 2SLS results indicate that the elasticity increases to about 4 to 6 percent, which is about two to three times larger than the OLS estimate, and explains about 30 percent of the property crime change during the 1990s.

In the first systematic analysis of how labor markets affect crime in France, Fougere et al. (2009) use both individual data and departement-level data (similar to county-level data in the U.S.) between 1990 and 2000. Using the predicted industrial structure to instrument unemployment, they contend that increase in unemployment increase burglaries, thefts, and drug offenses. Furthermore, changes in youth unemployment have particularly large effects on these offenses.

Some recent theoretical papers formally model this reverse causality. The models in Burdett et al. (2003) and Huang et al. (2004) allow crime, unemployment, and inequality to be 
endogenously determined using general equilibrium frameworks, which allows the authors to explore alternative interactions among the variables and to discuss some general-equilibrium effects that are often neglected.

Although many areas of economics have a long history of addressing endogeneity, only in recent years has research that examines how labor markets affect crime made a concerted effort to attend to this concern. In the past ten years, there have been a number of both theoretical and empirical papers that systematically seek to account for reverse causality. These initial efforts are promising and show that labor market proxies have consistent salutary effects on crime. Some, but not all, studies report substantially larger estimated effects with 2SLS than with OLS. Because these efforts are fairly modest, there are ample opportunities for future research to explore the nature and magnitude of the bias from reverse causality. Research from other nations that use different instruments and identification strategies will also help us better understand the degree to which endogeneity affects our estimates.

\section{How Should we Measure Labor Market Opportunities?}

There has also been an important change in the type of labor market variables that are commonly used. In the first few decades of this research, most studies used unemployment rates. This focus is evident in the titles of the early literature reviews. Freeman (1983) is titled "Crime and Unemployment" and Chiricos (1987) is titled "Rates of Crime and Unemployment". Piehl (1998) highlights one paper that uses wages, but it primarily examines the simultaneous response that participation in crime lowers earnings and employment rates Needles (1996). While Fagan and Freeman (1999) offer a detailed account of the research on how illegal wages affect crime, they discuss only one published paper and one working paper of how legal wages affect crime. 
While Freeman (1996), Wilson (1996), and Raphael and Winter-Ebmer (2001) speculate that the declining wages and employment opportunities of unskilled men contribute to their increasing involvement in crime, wages are rarely included as labor market measures compared to unemployment and average income, which are commonly used. This omission is surprising, because wages may be a better measure for the labor market prospects of potential criminals. Unemployment rates may drop even when underlying labor market conditions become worse, because people may leave the labor force if they think it unlikely that they will find work. More important, however, is that unemployment is often short-lived and highly cyclical. Given the potentially long-lasting effects of incarceration and investing in human capital specific to the criminal sector, crime may be more responsive to long-term changes in labor market conditions than to short-term fluctuations. A secular decline in unskilled wages, as seen during the late 1970s and 1980s, represents a decline in the permanent wages of uneducated workers, while cyclical unemployment fluctuations have more temporary implications.

Figure 1 clearly illustrates the different patterns of unemployment and wages for noncollege males who work full time and are between the ages of 18 and 65. In 1997, their unemployment rate was the same as it was in 1979, the first year of the period. During the intervening years, the unemployment rate increases slightly during the two recessions in the early 1980s and early 1990s and cycles back down. In sharp contrast, the real wage measure steadily decreases through most of the period and in 1997 was over 20 percent lower than it was in 1979.

Similarly, using county-level data, Figure 2 documents that between 1979 and 1997, per capita income increased 15 percent while wages dropped by over 30 percent in the retail sector, which employs a disproportionately large share of low-skilled men who are more likely to engage in illegal activity. Because the trends are distinctly different, relying on income and 
unemployment as proxies for the labor market prospects of low-skilled males will necessarily generate very different point estimates. Also, it is important to include both measures in the regressions to control for any correlation between the labor market prospects of less educated men and the overall economic prosperity of the area, which may proxy for the level of wealth available to steal.

Cornwell and Trumbull (1994) use seven years of county-level panel data from North Carolina primarily study how measures of deterrence affect crime. They do, however, include the average weekly wage for nine industries as control variables. These average wage measures show little consistent effect either in sign or the level of statistical significance.

Grogger (1998) is the first large-scale systematic study to explore the effect of wages on illegal activity and to control for a number of other factors. He uses a structural model with individual-level data from the NLSY, and estimates the relationship between wage offers and the property crimes committed by these young men. He finds that criminal participation of young men is negatively related to their potential wages, explaining "three-quarters of the observed rise in youth crime.” Grogger concludes that youth behavior responds to price incentives and that falling real wages were an important determinant of rising youth crime during the 1970s and 1980s. Moreover, wage differentials explain a substantial component of both the racial differential in criminal participation and the age distribution of crime.

Doyle et al. (1999) find that wages in the low-skilled sectors of wholesale and retail trade reduce crime, a result that is robust across many specifications. A one-percent increase in wages in the retail and wholesale sectors decreases crime by between 0.3 and 0.9 percent. This effect of wages on crime is larger than the effect of unemployment on crime and the effect sizes are larger for property than violent crime. 
Gould et al. (2002) use a non-structural approach to exploit the differences in the timing of wage changes across geographic areas. In alternative specifications they use the weekly wage of non-college educated males and the retail wage, which is a proxy for the wages of noncollege-educated men. They find that increases in the wages of low-skilled men reduce property crime more than violent crime and that wage measures are much more important than unemployment for explaining the changes in crime rates. They also explain the ten-year change in crime rates by the ten-year change in the average wage and unemployment rate of non-college men. This strategy exploits the low frequency variation in the data. Given the long-term consequences of criminal activity, crime should be more responsive to low frequency changes in labor market conditions. This long-term regression approach also attenuates measurement error problems in panel regression analyses. Griliches and Hausman (1986) and Levitt (1998) discuss advantages of the "long regression" in the presence of measurement error.

Hansen (2003) explores the role of education on crime. She uses self-reported survey data collected from 2,529 young males aged 16-25 in England and Wales to contrast the age-crime profiles of those who left school at age 16 with those who continue their education past the compulsory school leaving age. She documents that for all ages and all three offense types (property offenses, handling offenses, and violent offenses), the crime-age profiles for the less educated are higher than the profile for the more educated group. The gap is reduced when controlling for other factors, including the specific school that one attended.

Narayan and Smyth (2004) apply Granger causality tests to examine the relationship between seven categories of property and violent crime with male youth unemployment and real male average weekly earnings in Australia from 1964 to 2001 within a cointegration and vector error correction framework. They conclude that fraud, homicide and motor vehicle theft are 
cointegrated with male youth unemployment and real male average weekly earnings. However, they find no evidence of a long-run relationship between breaking and entering, robbery, serious assault or stealing with male youth unemployment and real male average weekly earnings.

Machin and Meghir (2004) use the New Earnings Survey (NES) to obtain panel data on the police force areas of England and Wales between 1975 and 1996. They examine how changes in wages at the bottom end of the distribution affect crime rates. They use different wage measures to identify those who are on the margins of legal and illegal activity. They use the $25^{\text {th }}$ percentile of both the overall wage distribution, the wages in the retail sector where low-skill workers typically work, and a selection corrected wage, which they interpret as the absolute value of the lower bound of the impact of wages on crime. Machin and Meghir conclude that coefficient estimates of the unemployment rate are not statistically significant; once they control for wages, unemployment is of little importance. However, they also find that decreases in the wages of low-wage workers increase vehicle, theft, and burglary.

In a theoretical paper Lochner (2004) develops a model of crime in which human capital increases the opportunity cost of crime from foregone work and expected costs associated with incarceration. He contends that the underlying human capital of potential offenders may be even more influential than wages in affecting crime, and explores the effects of education, training, and wage subsidies on criminal behavior.

To summarize, we can use many measures of labor market opportunities and we need to think carefully about which labor market measures are best suited for the theory. Although historically the emphasis has largely been placed on using unemployment rates (which exhibit little long-term trend) or per capita income (which shows some small increases), these measures have demonstrably different time patterns than the wages of low-skilled, poorly educated men, 
which have dropped substantially in recent decades. Despite the marked differences in methods, data, and nation of study, research that includes both unemployment and wages consistently find that wages are much more important for explaining variations in crime than are unemployment rates. Further efforts to expand the traditional measure of labor market success to include wages and underlying measures of human capital are promising avenues of research.

\section{Averages or Margins?}

Historically, the most commonly used variables to proxy the labor market opportunities are average income, wages, and unemployment rates. Although Ehrlich (1973) carefully identifies the problems that average measures may create, researchers have too often included average measures of labor market success in the regressions without carefully evaluating exactly how they relate to the underlying variables of theoretical interest. Ideally, we want to identify the variables that best measure the labor market opportunities for those who are on the margin of substituting between the legal and illegal sectors.

Population averages may be problematic for a few reasons. First, they may not identify those who are on the margin and are the most likely to substitute from one sector to another. Suppose that the average income in an area decreases or its average unemployment rate increases because of a disproportionately large drop in employment opportunities for those in the high end of the income distribution. While such a change clearly reduces average employment opportunities, it may have little impact on crime rates, because few people in the high income group will engage in illegal activity. Conversely, a disproportionately large drop in market opportunities for those who are on the margin between the sectors will moderately reduce the 
average measures, but may have a significant impact on crime. In either case, the estimated effects will be biased because the averages either overstate or understate the true impact.

This type of analysis goes beyond high and low-income people. Men engage in criminal activity at much higher rates than women, people between the ages of 16 and 24 are more likely to commit crime than the elderly, and those with relatively little education commit crime at higher rates than those with a lot of education. Because these differences are large and important, we must strive to identify variables that truly measure the labor market opportunities for people on the margin if legal and illegal activity.

A second problem in using averages is that they may have multiple effects that offset each other. For example, high unemployment may increase the crime rate by lowering the marginal return to legitimate earning activities and increasing the time available to engage in criminal activity. High unemployment may simultaneously attenuate crime by reducing the supply of suitable targets and increasing the probability that an offender is caught by having more people at home. Similarly, a region that has higher income may have greater opportunities for people to substitute from the illegal labor market into the legal one, but may also have more resources available for criminals to steal. Additionally, higher income individuals invest more in self-protection from criminals, which may attenuate crime. For example, Lott and Mustard (1997) and Ayres and Levitt (1998) showed that self-protection lowers crime by carrying concealed weapons and purchasing Lojack, respectively. Benson and Mast (2001) examine the role of privately produced deterrence more broadly. These multiple effects that work in opposite direction help explain why empirical studies show mixed results in different studies.

Interestingly, early contributors to this field Fleisher (1963, 1966) and Ehrlich (1973) clearly explain how labor market measures may pick up multiple effects, and they take pains to 
explain that it is important to estimate these effects separately. Unfortunately, this point has been missed or underemphasized too often among subsequent scholars.

Some recent papers identify labor market measures for those who are on the margin. Gould et al. (2002) use per capita income to control for the general level of prosperity in the area and use various measures of low-skilled wages to isolate the effect of labor market opportunities from the regional economic trends. From the Current Population Survey, they calculate the wages of low-skilled, poorly-educated men and they also use the wages in the retail sector. They study whether local crime rates respond to the labor market conditions of those most likely to commit crime—unskilled men—rather than testing whether crime rates respond to the general economic conditions of the area.

Machin and Marie (2006) study how the introduction of the UK Job Seeker’s Allowance, which strengthened the qualification standards to receive unemployment benefits, affected crime. They find that this change in the law mainly influences people who are on the margin of engaging in criminal activity.

The minimum wage is also used to target those who may be more likely to experience an increase in criminal participation as a result of labor market conditions. Hansen and Machin (2002) use Britain's introduction of a national minimum wage in April 1999 as a natural experiment. They calculate difference-in-difference estimators to uncover a statistically significant link between changes in crime and the degree to which people in the area earn low pay before the minimum wage was introduced.

Corman and Mocan (2005) use monthly time-series data from New York City between 1974 and 1999 to investigate the effect that both deterrence and economic variables, such as the unemployment rate and real minimum wage, have on crime. While both types of variables help 
explain the decline in crime, the contribution of deterrence measures is larger than those of economic variables.

In sum, studies that target labor market measures for those most likely to commit crimespecifically low-skilled young men and those who are employed in the low-paying retail sector-provide more convincing evidence to buttress the claim that labor market prospects and success reduce illegal activity.

\section{Conclusion and Future Research}

Much of the extensive 50-year-old literature that examines how labor markets affect crime is characterized by a central theme-there is a large disconnect between the theory that claims that better labor markets should reduce crime and the empirical research that has been unable to consistently document such a relationship. However, in the last ten years, research has addressed many of the problems that made it difficult to identify this relationship. A number of conclusions emerge from this new generation of research. First, the use of data at local levels like cities, counties, and census tracts, is now standard when using aggregate data. These studies are much more likely to document relationships between labor markets and crime than research that uses larger areas of aggregation. Because crime varies in important ways across even relatively small geographic areas, national or state-level data mask much of the important variation that is needed to identify causation. Although studies using individual data are less common, they also generally document strong linkages between the legal and illegal sectors.

Second, nearly every study that uses panel data finds economically and statistically significant relationships between labor markets and crime. Panel data estimation techniques like 
fixed effects for regions and years control for unobserved differences and consequently reduce omitted variable bias. The studies that use cross section and repeated cross section data can control for fewer alternative explanations and show more ambiguous results.

Third, while the first three decades of research focused primarily on unemployment rates to proxy for labor markets, more recent studies analyze a broader array of measures, such as wages, education, and human capital. Because unemployment (which tends to be cyclical) and wages show markedly different time trends, studies with these alternative measures will necessarily provide different results. Furthermore, wages may better measure the underlying labor market opportunities, especially for low-skilled and poorly-educated males who are most likely to be on the margin of engaging in illegal activity. The studies that use both wages and unemployment generally find that wages explain more of the variation in crime than does unemployment.

Fourth, although many papers explore how crime influences wages, employment, and the growth of and location decisions of firms, little research attempts to control for this reverse causality to identify the effect of labor markets on crime. Early efforts to use instrumental variables and natural experiments to isolate the causal effects show mixed results about the magnitude of the bias due to reverse causation.

Fifth, the growing use of data from countries outside of the United States is interesting and beneficial for many reasons. In recent decades, the U.S. experienced different trends in illegal activity compared to many other industrialized and developing nations. Also, data from other nations present opportunities to understand crime in different contexts and to use new identification strategies. This is especially true for exploring endogeneity, which may require novel instruments or natural experiments. 
The new generation of studies in the last 10 years has made important progress in helping us better understand the relationship between labor markets and crime. The chief result is that the gap between the theory and empirical work that was once wide has been significantly narrowed. Research that best measures the labor market prospects of those who are most likely to engage in the illegal sector, and that best addresses important empirical problems, consistently shows that legal labor market opportunities substantially reduce crime. Some research estimates elasticities to be greater than one for some labor market measures on property crime and robbery, and others conclude that labor market measures explain up to 30 percent of the changes in property crime and robbery in the U.S. Labor markets have a more modest effect on the remaining violent crimes. For murder, rape, and aggravated assault the coefficient estimates on labor market variables are smaller and the results show mixed levels of statistical significance.

In considering future research, the common tendency is to issue a call for more papers. However, because this gap between theory and empirics existed for so long in spite of a large number of papers, an appeal for more research will not significantly influence the field. Instead, high quality new research will take careful note of how the recent wave of scholarship has made important progress in resolving many consequential problems. Important advances can be made by continued use of better data and econometric techniques, exploring the data from other nations, analyzing the effects of a broader range of labor market measures, and finding new ways through natural experiments and other identification strategies to better identify the underlying relationship. 


\section{References}

Allgood, Sam, David B. Mustard, and Ron Warren. 2006. "The Impact of Youth Criminal Behavior on Adult Earnings,” Working Paper.

Arvanites, Thomas M. and Robert H. Defina. 2006. "Business Cycles and Street Crime.” Criminology, 44 (1): 139-164.

Ayres, Ian and Steven D. Levitt. 1998. "Measuring Positive Externalities from Unobservable Victim Precaution: An Empirical Analysis of Lojack.” Quarterly Journal of Economics, 113 (1): $43-77$.

Becker, Gary S. 1968. “Crime and Punishment.” Journal of Political Economy, 76 (2): 169-217.

Benson, Bruce L. and Brent D. Mast. 2001. “Privately Produced General Deterrence.” Journal of Law and Economics. 44 (2, Pt. 2): 725-746.

Blumstein, Alfred and Joel Wallman. 2006. “The Crime Drop and Beyond.” Annual Review of Law and Social Science, 2: 125-146.

Burdett, Kenneth, Ricardo Lagos, and Richard Wright. 2003. "Crime, Inequality, and Unemployment.” American Economic Review, 93 (5) December: 1764-1777.

Bushway, Shawn and Peter Reuter. 2001. “Labor Markets and Crime.” In Crime: Public Policies for Crime Control, editors James Wilson and Joan Petersilia. San Francisco: CA: ICS Press: 191-224.

Cantor, David and Kenneth C. Land. 1985. “The Unemployment and Crime Rates in the PostWorld War II United States: A Theoretical and Empirical Analysis.” American Sociological Review, 50 (3): 317-332.

Chiricos, Theodore. 1987. "Rates of Crime and Unemployment: An Analysis of Aggregate Research Evidence.” Social Problems, 34: 187-212. 
Corman Hope and Naci Mocan. 2005. "Carrots, sticks, and broken windows.” Journal of Law and Economics, 48 (1): 235-266.

Cornwell, Christopher and William N. Trumbull, 1994. "Estimating the Economic Model of Crime with Panel Data.” Review of Economics and Statistics, 76 (2): 360-366.

Cullen, Julie Berry and Steven D. Levitt. 1999. “Crime, Urban Flight, and the Consequences for Cities.” Review of Economics and Statistics, 81 (2): 159-169.

Doyle, Joanne M., Ehsan Ahmed, and Robert N. Horn. 1999. “The Effects of Labor Markets and income Inequality on Crime: Evidence from Panel Data.” Southern Economic Journal, 65 (4): 707-738.

Edmark Karin. 2005. Unemployment and crime: Is there a connection? Scandinavian Journal of Economics, 107 (2): 353-373.

Ehrlich, Isaac. 1973. "Participation in Illegitimate Activities: A Theoretical and Empirical Investigation.” Journal of Political Economy, 81 (3): 521-565.

Fagan, Jeffrey and Richard B. Freeman. 1999. “Crime and Work.” In Crime and Justice, Vol. 25: 225-290.

Fleisher, Belton M. 1963. “The Effect of Unemployment on Juvenile Delinquency.” Journal of Political Economy, 71 (6) (Dec.): 543-555.

Fleisher, Belton M. 1966. “The Effect of Income on Delinquency.” American Economic Review, 56 (1/2) (March): 118-137.

Fougere, Denis, Francis Kramarz, and Julien Pouget. 2009. "Youth Unemployment and Crime in France.” Journal of the European Economic Association, 7 (5): 909-938.

Freeman, Richard B. 1983. “Crime and Unemployment.” In Crime and Public Policy, edited by James Q. Wilson. San Francisco: Institute for Contemporary Studies Press. 
Freeman, Richard B. 1992. "Crime and the Employment of Disadvantaged Youth.” In Urban Labor Markets and Job Opportunity, edited by George Peterson and Wayne Vroman. Washington, DC: Urban Institute Press.

Freeman, Richard B. 1995. “The Labor Market” In Crime: Public Policies for Crime Control, editors James Wilson and Joan Petersilia, San Francisco: CA: ICS Press: 171-192.

Freeman, Richard B. 1996. "Why Do So Many Young American Men Commit Crimes and What Might We Do About It?” Journal of Economic Perspectives, 10 (Winter): 25-42.

Freeman, Richard B. 1999. "The Economics of Crime.” Handbook of Labor Economics, 3c, edited by O. Ashenfelter and D. Card. Elsevier Science.

Freeman, Richard B. and William M. Rodgers III. 1999. “Area Economic Conditions and the Labor Market Outcomes of Young Men in the 1990s Expansion,” NBER Working Paper 7073, April.

Glaeser, Edward and Bruce Sacerdote. 1999. "Why Is There More Crime in Cities?” Journal of Political Economy, 107 (6), part 2: S225-S258.

Glaeser, Edward, Bruce Sacerdote, and Jose Scheinkman. 1996. “Crime and Social Interactions.” Quarterly Journal of Economics, 111: 507-548.

Glueck, Sheldon and Eleanor Glueck. 1950. Unraveling Juvenile Delinquency. New York, NY: Commonwealth Fund.

Gould, Eric D., Bruce A. Weinberg, and David B. Mustard. 2002., “Crime Rates and Local Labor Market Opportunities in the United States: 1977-1997.” The Review of Economics and Statistics, 84 (1): 45-61.

Greenbaum, Robert T. and George E. Tita. 2004. "The Impact of Violence surges on Neighborhood Business Activity.” Urban Studies, (13): 2495-2514. 
Griliches, Zvi and Jerry Hausman. 1986. "Errors in Variables in Panel Data.” Journal of Econometrics, 31: 93-118.

Grogger, Jeff. 1995. "The Effect of Arrests on the Employment and Earnings of Young Men.” Quarterly Journal of Economics, 110 (1): February: 51-72.

Grogger, Jeff. 1998. "Market Wages and Youth Crime.” Journal of Labor Economics, 16 (October): 756-791.

Hansen, Kirstine. 2003. "Education and the crime-age profile.” British Journal of Criminology, 43 (1) Winter: 141-168.

Hansen, Kirstine and Stephen Machin. 2002. "Spatial crime patterns and the introduction of the UK minimum wage.” Oxford Bulletin of Economics and Statistics, 64 (August): 677-697.

Huang, Chien-Chieh, Derek Laing, and Ping Wang. 2004. "Crime and Poverty: A Searchtheoretic Approach.” International Economic Review, 45 (3): 909-938.

Ihlanfeldt, Keith. 2007. "Neighborhood drug crime and young males' job accessibility.” The Review of Economics and Statistics, 89 (1) (February): 151-164.

Levitt, Steven D. 1998. “Why Do Increased Arrest Rates Appear to Reduce Crime: Deterrence, Incapacitation , or Measurement Error?” Economic Inquiry, 36 (3) July: 353-372.

Levitt, Steven D. 2001. “Alternative Strategies for Identifying the Link Between Unemployment and Crime,” Journal of Quantitative Criminology, 17 (4) December: 377-390.

Levitt, Steven D. 2004. "Understanding Why Crime Fell in the 1990s: Four Factors that Explain the Decline and Six that Do Not.” Journal of Economic Perspectives, 18 (1): 163-190.

Lin, Ming-Jen. 2008. “Does Unemployment Increase Crime? Evidence from the U.S. Data 19742000.” Journal of Human Resources, 43 (2): 413-436. 
Lochner, Lance. 2004. "Education, Work, and Crime: A Human Capital Approach." International Economic Review, 45(3): 811-43 (August).

Lochner, Lance and Enrico Moretti. 2004. "The effect of education on crime: Evidence from prison inmates, arrests, and self-reports.” American Economic Review, 94 (1) March: 155-189.

Long, Sharon K. and Ann D. Witte. 1981. "Current economic trends: implications for crime and criminal justice.” In Crime and Criminal Justice in a Declining Economy, edited by Kevin N. Wright, Cambridge, MA: Oelgeschlager, Gunn and Hain: 69-143

Lott, John R., Jr. 1992. “An Attempt at Measuring the Total Monetary Penalty from Drug Convictions: The Importance of an Individual’s Reputation.” Journal of Legal Studies, 21 (January): 159-187.

Lott, John R., Jr. and David B. Mustard. 1997. "Crime, Deterrence, and Right-to-Carry Concealed Handguns.” Journal of Legal Studies, 26 (January): 1-68.

Machin, Stephen and Costas Meghir. 2004. “Crime and economic incentives.” Journal of Human Resources, 39 (4) Fall: 958-979.

Machin, Stephen and Olivier Marie. 2006. “Crime and benefit sanctions.” Portuguese Economic Journal, 5 (2): 149-165.

Mehlum, Halvor, Edward Miguel, and Ragnar Torvik. 2006. "Poverty and Crime in $19^{\text {th }}$ Century Germany.” Journal of Urban Economics, 59 (3): 370-388.

Narayan, Paresh Kumar and Russell Smyth. 2004. "Crime Rates, Male Youth Unemployment and Real Income in Australia: Evidence from Granger Causality Tests.” Applied Economics, 36 (18) October: 2079-2095. 
Needels, Karen. 1996. “Go Directly to Jail and Do Not Collect? A Long-Term Study of Recidivism and Employment Patterns Among Prison Releasees.” Journal of Research in Crime and Delinquency, 33:471-496.

Papps, Kerry and Rainer Winkelmann. 2002. "Unemployment and Crime: New Evidence for an Old Question,” New Zealand Economic Papers, 34 (1): 53-72.

Piehl, Anne. 1998. "Economics Conditions, Work and Crime." In Handbook of Crime and Punishment. Editor Michel Thorny. New York: Oxford University Press.

Raphael, Stephen and Rudolf Winter-Ebmer. 2001. "Identifying the Effect of Unemployment on Crime.” Journal of Law and Economics, 44 (1): 259-283.

Reuter, Peter, Robert MacCoun, and Patrick Murphy. 1990. Money from Crime: A Study of the Economics of Drug Dealing in Washington, DC. Santa Monica, CA: The RAND Corporation.

Roback, Jennifer. 1982. "Wages, Rents, and the Quality of Life.” The Journal of Political Economy, 90 (6) Dec.: 1257-1278.

Sampson, Robert J. and John H. Laub. 1990. "Crime and Deviance over the Life Course: The Salience of Adult Social Bonds.” American Sociological Review, 55 (October): 609-627.

Sampson, Robert J. and John H. Laub. 1997. “A Life-course Theory of Cumulative Disadvantage and the Stability of Delinquency.” In Developmental Theories of Crime and Delinquency: Advances in Criminological Theory, edited by Terence P. Thornberry, Vol. 6, New Brunswick, NJ: Transaction Publishers.

Topel, Robert H. 1994. "Regional Labor Markets and the Determinants of Wage Inequality." American Economic Review, 84 (May): 17-22. 
Willis, Michael. 1997. “The Relationship between Crime and Jobs.” University of California-Santa Barbara, Working Paper, May.

Wilson, William Julius. 1996. When Work Disappears: The World of the New Urban Poor, New York: Alfred A. Knopf. 
Figure 1

Standardized Wages and Unemployment Rates of Non-College Men

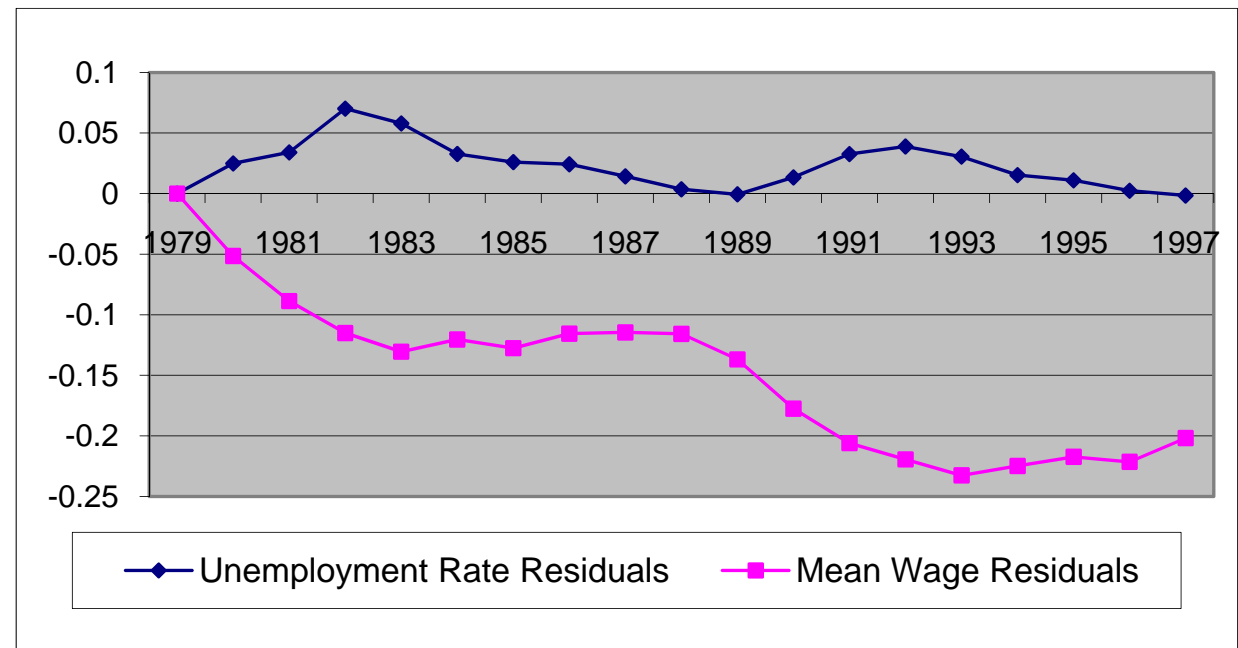

Source: Gould et al. (2002) Figure 6. The data were computed from the Current Population Survey. Non-college males are defined as full-time males between the ages of 18 and 65 . Residuals were computed after controlling for a quartic in potential experience, years of school (within non-college), race (black and non-white, non-black), Hispanic background, region of residence, and marital status. Wages deflated to 1982-1984=100 dollars. Mean residuals for each year were standardized to the base year 1979 .

Figure 2

Retail Wages and Income Per Capita between 1979 and 1997

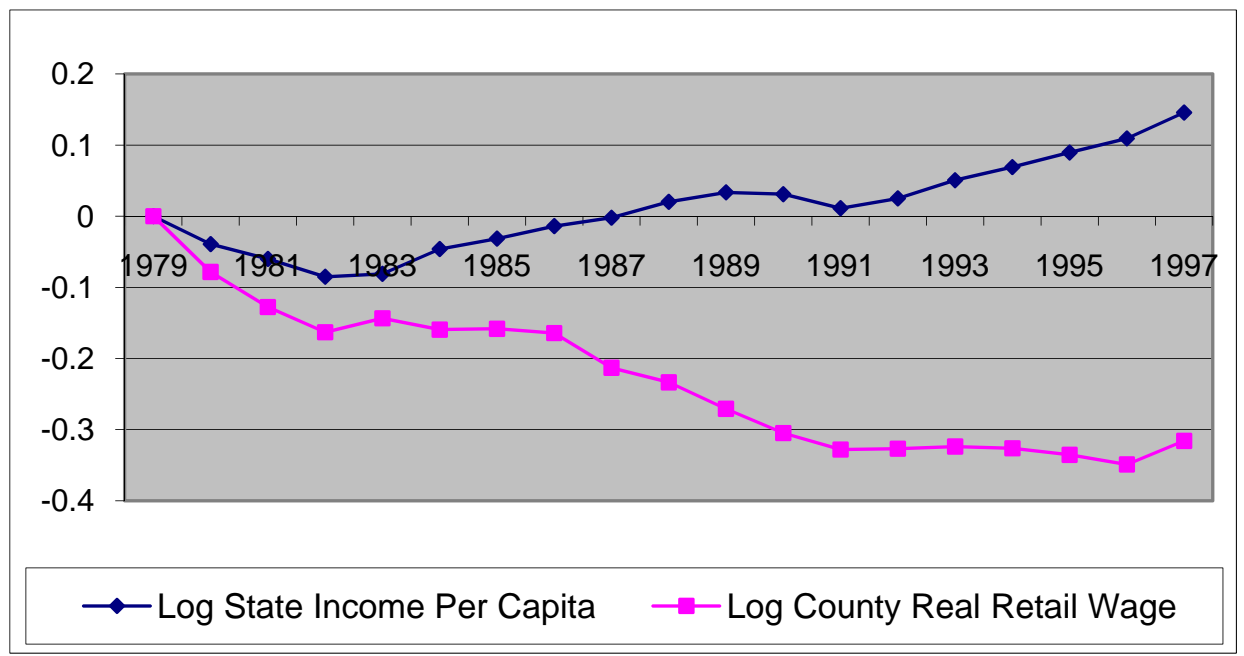

Source: Gould et al. (2002) Figure 7. The plotted values are the coefficient estimates on the time dummies of county-level regressions of the log offense rates on time dummies, county fixed effects, and controls for age and population distributions, the sex composition, and the percentages of the population that are black and neither white, nor black. 